\title{
SPOŁECZNOŚĆ KOŚCIOŁA AFRYKI RZYMSKIEJ W RELACJI ŚW. AUGUSTYNA
}

\author{
DOI: http://dx.doi.org/10.12775/SPLP.2019.034
}

\section{Streszczenie}

W artykule tym zaprezentowane zostały wybrane uwagi na temat późnoantycznej społeczności chrześcijan Kościoła Afryki rzymskiej w relacji św. Augustyna. Odwołując się do dzieł biskupa Hippony, mogliśmy zanalizować pewien wycinek obrazu społeczeństwa rzymskiego w prowincji afrykańskiej dotyczący kwestii stosunków religijnych w ówczesnych strukturach kościelnych. Nie jest to obraz pełny, zajęliśmy się w tym miejscu tylko wybranymi zagadnieniami, ponieważ kolekcja źródeł Augustyna jest nader bogata i mimo wielości opracowań na ten temat, wciąż można odkrywać nowe zagadnienia czy problemy, bądź też analizować opracowane już na nowy sposób. W powyższym artykule zajęliśmy się kwestiami związanymi z duchowieństwem afrykańskim, przebiegiem liturgii, ogólnie pojętym laikatem i jego służbą kościelną oraz stosunkami religijnymi, zawężonymi do zagadnień herezji i schizm. Sam temat podjęty przez nas w artykule wymaga dalszych badań, jednak przedstawione powyżej wnioski pozwalają stwierdzić, że mimo problemów z gospodarką w III wieku, kryzysami, uzurpacjami, a nade wszystko z herezjami, schizmami i koniunkturalnymi nawróceniami, Kościół afrykański w czasach św. Augustyna rozwijał się dobrze, a próby walki z problemami podejmował charyzmatyczny biskup Hippony, wspierany przez hierarchię kościelną.

Słowa kluczowe: św. Augustyn; Afryka rzymska; chrześcijaństwo antyczne; duchowieństwo IV $i$ V wieku; późnoantyczne społeczeństwo rzymskie; Kościót starożytny; stosunki religijne 


\author{
Remarks on the Christian Community \\ of the Roman Africa Church Made in Saint Augustine's Writings
}

\title{
Summary
}

This article presents selected remarks that St Augustine made on the late-classical Christian community of the Church in Roman. Looking at the writings of the bishop of Hippo we can analyse a certain section of Roman society in the African province, especially the question of the confessional relations in the Church structures of those days. However, this is not a complete image and we are able to deal only with some selected topics here. This is due to the fact that the collection of the Augustine sources is very complex and despite the numerous studies on this subject, new doubts and questions still arise. The paper contains a study of the African clergy, the liturgical rite, the laity in general and its ecclesiastical functions as well as the religious tensions caused by heresies and schisms. Undoubtedly the subject itself requires further research, yet the conclusions presented in the article allow us to say that despite the economic problems in the third century, the crises, the usurpations of power and, above all, the heresies, the schisms and the opportunistic conversions, the African Church in the time of St. Augustine was developing well. The charismatic bishop of Hippo was doing his best to tackle all these difficulties with the support of his clergy.

Keywords: Saint Augustine; Roman Africa; ancient Christianity; 3rd - 4thcentury clergy; late-classical Roman society; ancient Church; confessional relations

Dzieje Afryki rzymskiej zostały już szczegółowo opracowane ${ }^{1}$, podobnie jak administracja rzymska prowincji rozciągających się wzdłuż afrykańskiego

\footnotetext{
Zob. Afrika und Rom in der antike, hrsg von H. J. Diesner, H. Barth, H. D. Zimmermann, Verlag Halle Univ., Halle 1968; T. Kotula, Afryka Pótnocna w starożytności, Zakład Narodowy im. Ossolińskich, Wrocław 1972; T. Sarnowski, Les représentations de villas sur les mosaïques africaines tardives, Zakład Narodowy im. Ossolińskich, Wrocław 1978; B. Degórski, Kler afrykański w świetle synodów IV i V wieku, „Vox Patrum” 22 (2002), t. 42-43, s. 219-238; L. Manton, Roman North Africa, Batsford Ltd., Batsford 1988; A. G. Hamman, Życie codzienne w Afryce Pótnocnej w czasach św. Augustyna, Instytut Wydawniczy PAX, Warszawa 1989; M. Euzennat, Le limes de Tingitane, Editions du CNRS, Paris 1989; J. Strzelczyk, Wandalowie i ich afrykańskie państwo, Państwowy Instytut Wydawniczy, Warszawa 1992; S. Raven, Rome in Africa, Routledge, London 1993; A. H. Merrills, Vandals, Romans and Berbers. New Perspectives on Late Antique North Africa, Routledge, Aldershot 2002; A. Wilson, Urban production in the Roman World: The View from North Africa, „Papers of the British School at Rome” 70 (2002), s. 231-273; Y. Le Bohec, L'Afrique romaine. 146 avant J.-C-439 après J.-C., Picard, Paris 2005;
} 


\section{wybrzeża ${ }^{2}$. W niektórych zagadnieniach wciąż jednak pozostają niezbadane} lub do końca nie wyjaśnione problemy badawcze. Ciekawą kwestią pozostaje stopień chrystianizacji Afryki, a także geneza chrześcijaństwa w regionie $^{3}$. Wiemy, że ok. 180 r. n.e. w Afryce znajdowało się dość dużo i prężnie działających grup chrześcijańskich, które w spotkaniach używały łacińskich przekładów Pisma Świętego oraz skupiały osoby ze wszystkich warstw społecznych, co w późniejszej ewangelizacji oraz ostatecznym zyskaniu przewagi chrześcijaństwa $\mathrm{w}$ regionie na przełomie III i IV wieku miało

B. Cabouret, M. P. Arnaud-Lindet, L'Afrique romaine de 69 à 439, Editions du Temps, Nantes 2005; P. Corbier, M. Griesheimer, L'Afrique romaine: 146 av. J.-C.-439 ap. J.-C., Ellipses Marketing, Paris 2005; Y. Lafond, H. Guiraud, L'Afrique romaine: Ier siècle avant J.-C., début Ve siècle après J.-C., Presses Universitaires du Mirail, Toulouse 2005; A. Ibba, G. Traina, L'Afrique romaine: De l'Atlantique à la Tripolitaine (69-439 ap. J.-C.), Bréal, Paris 2006; M. Le Glay, Le paganisme en Numidie et dans les Maurétanies sous l'Empire romain: état des recherches entre 1954 et 1990, „Antiquités Africaines” 42 (2006), s. 57-86; M. Mackensen, G. Schneider, Production centres of African Red Slip ware (2nd-3rd c.) in northern and central Tunisia: archeological provenance and reference groups based on chemical analysis, „Journal of Roman Archeology” 19 (2006), s. 163-190; J. Stewart, African states and rulers, McFarland, Jefferson 2006; P. Kenrick, Tripolitania, Silphium Press, London 2009; D. Whittaker, Ethnic discourses on the frontiers of Roman Africa, w: Ethnic Constructs in Antiquity. The Role of Power and Tradition, red. T. Derks, N. Roymans, Amsterdam University Press, Amsterdam 2009, s. 189-206; J. Hoffman-Salz, Die wirtschaftlichen Auswirkungen der römischen Eroberung. Vergleichende Untersuchungen der Provinzen Hispania Tarraconensis, Africa Proconsularis und Syria, Franz Steiner Stuttgart, Mainz 2011 (zwłaszcza s. 154-293); J. Conant, Staying Roman. Conquest and Identity in Africa and the Mediterranean, Cambridge University Press, Cambridge 2012.

2 Zob. T. Kotula, Zgromadzenia prowincjonalne w rzymskiej Afryce w epoce późnego cesarstwa; Sz. Olszaniec, Prefektura praetorio Italii, Illyrikum i Afryki (312-425 n.e.), Wydawnictwo Uniwersytetu Mikołaja Kopernika, Toruń 2014.

3 Przede wszystkim zaznaczyć należy, że nie mamy żadnych danych dotyczących początków chrześcijaństwa w Afryce i właściwie nie jest pewnym, skąd przybyli pierwsi wyznawcy Chrystusa. Por. P. Moncaeaux, Histoire littéraire de l'Afrique Chrétienne, Tertullien et les origines, Editions Ernest Leroux, Paris 1901, vol. 1, s. 3-4. Tertulian, wydający się być najbliżej sformułowania hipotezy o pierwszych chrześcijanach, również nie daje odpowiedzi, poza stwierdzeniem, że teologicznie Kościół afrykański pochodzi od Rzymu, co jednak nie rozwiązuje kwestii przybycia pierwszych chrześcijan do Afryki w żaden sposób. Por. Tertullianus, De praescriptione 36, CPL 5. Dopiero Augustyn, analizując różne przekazy (po części nam nieznane) dochodzi do lakonicznego wniosku, że Ewangelię Afryce przyniesiono ze Wschodu. Por. Augustinus, Ep. 43, 7, PL 33; tenże, Ep. 52, 2, PL 33. Nie wyjaśnia niestety, czy Wschód to dla niego po prostu Palestyna, czy jakieś inne ziemie. Może tu chodzić także o Azję Mniejszą, Egipt, Libię lub nawet Rzym, choć według J. Słomki prawdopodobnie w Afryce chrześcijaństwo pojawiło się mniej więcej w tym samym czasie ze wszystkich wymienionych kierunków. Por. J. Słomka, Eklezjalno-teologiczne podstawy praktyki pokutnej wprowadzonej przez Cypriana w Kartaginie, „Śląskie Studia Historyczno-Teologiczne” 42/2 (2009), s. 116. 
niebagatelne znaczenie ${ }^{4}$. Chrześcijanie w Afryce przed edyktem Konstantyna odznaczali się charakterystyczną gloryfikacją męczeństwa, ponieważ, o czym warto wspomnieć, według wpływowego Tertuliana nawet ucieczka przed nim była ogromną hańbą ${ }^{5}$.

Dużą liczbę katolików w Afryce rzymskiej ${ }^{6}$ już w połowie III wieku potwierdza nam Cyprian z Kartaginy - ,de unitate Patris et Filii et Spiritus sancti

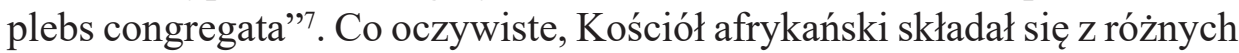
rodzajów ludzi i osobowości; oprócz zwyczajnych mieszkańców, znajdowali się tam też bandyci, łajdacy czy rozpustnicy ${ }^{8}$. Na nabożeństwa niektórzy przychodzili w aurze świętobliwości, jednak ich życie nie było tego przykładem ${ }^{9}$. Biskupi katoliccy doskonale wiedzieli o tym, że w Kościele wielu jest słabych duchem ${ }^{10}$. W niniejszym artykule zajmiemy się społecznością Kościoła afrykańskiego w relacji św. Augustyna ${ }^{11}$.

4 Wnioski takie wyciągnąć możemy na podstawie lektury Acta Scillitanorum (ok. 180 r.), a także Acta Perpetuae et Felicitatis (ok. 203 r.), gdzie mamy żywy obraz społeczności chrześcijańskiej w czasach prześladowań. Akta te przynoszą także informacje szczegółowe, które pozwalają nam chociaż w niewielkim stopniu na próbę rekonstrukcji obrazu i genezy chrześcijańskiego społeczeństwa w Afryce. W przypadku Acta Scillitanorum widzimy, że chrześcijanie to prężne i młode grupy, skupiające niższe warstwy społeczne (głównie chłopstwo), natomiast autor Acta Perpetuae et Felicitatis wielokrotnie podkreśla wykształcenie i wysoką pozycję społeczną Perpetuy. Por. Acta Scillitanorum; Acta Perpetuae et Felicitatis, w: Acts of the Christian Martyrs, Oxford University Press, Oxford 1972. Na temat pochodzenia Perpetuy por. Passio Perpetuae 2. Felicyta natomiast była niewolnicą, ale różnice społeczne miały zaniknąć w Chrystusie. Por. tamże, 20. Ponadto warto wspomnieć, że święto Perpetuy i Felicyty było w Afryce rzymskiej jednym z najważniejszych świąt chrześcijańskich poświęconych męczennikom. Obchodzono je 7 marca. Por. Depositio martyrum, mense Martio, non. Martias Perpetuae et Felicitatis, Africae, MGH AA IX, s. 71.

5 Por. Tertullianus, De fuga in persecutione 5, CCSL II; tamże 9, 4, CCSL II. Na temat chrześcijańskiej mentalności czasów prześladowań i służby w męczeństwie zob. tenże, Ad martyras, CCSL I.

6 Augustinus, Sermo 115, 1, PL 38.

7 Cyprianus, De Dominica Oratione 23, CCSL III A.

8 Augustinus, En. in Ps. 99, 12, PL 37.

9 Tamże 120, 28, PL 37.

10 Tamże 21 (2), 15, PL 36.

11 Na temat życia św. Augustyna por. C. Cremona, Augustin d'Hippone, Éditions Pierre Téqui, Paris 1987; J.C. Eslin, Saint Augustin. L'homme occidental, Michalon, Paris 2002; W. Geerlings, Augustinus - Leben und Werk. Eine bibliographische Einführung, Verlag Ferdinand Schöningh, Paderborn 2002; L. Jerphagnon, Saint Augustin. Le pédagogue de Dieu, Gallimard, Paris 2002; G. Santi, Agostino d'Ippona filosofo, Lateran University Press, Roma 2003; D. Doucet, Augustin, Paris 2004; J.J. O’Donnell, Augustine. A New Biography, Harper Perennial, New York 2005; A. Trapè, Introduzione generale a sant'Agostino, Citta Nuova Editrice, Roma 2006; K. Pollman, Saint Augustine the Algerian, Göttinger Forum für Altertumswissenschaft, Göttingen 2007; W. Harmless, Augustine in his own words, The Catholic University of America Press, Washington 2010; M.A. Vannier, Saint Augustin, Entrelacs, Paris 2011; G.J. Bellinger, Die Lebensgeschichte 


\section{DUCHOWIEŃSTWO AFRYKAŃSKIE W IV I V WIEKU}

Dyscyplina duchowieństwa afrykańskiego była tematem wielu prac naukowych $^{12}$. W Afryce czasów św. Augustyna nie było ustalonego kanonu Pisma Świętego. Powszechnie obowiązywała Vetus Versio Latina, natomiast tłumaczeniu dokonywanemu przez Hieronima - Vulgacie Hieronima nie było łatwo wejść do codziennego użytkowania, choć od połowy $\mathrm{V}$ wieku zaczęto coraz częściej je stosować13.

Starano się przede wszystkim, żeby Kościół kojarzono z uczciwością. Augustyn był bardzo skrupulatny w kwestiach kontroli majątku swojej diecezji. Pamiętać należy bowiem, że jednym z głównych zadań biskupa miejsca było zadbanie o to, żeby duchowni żyli w ubóstwie, od którego nie mogło być odstępstwa ${ }^{14}$. Gromadzenie majątku tworzyło też problemy, oprócz plotek i oskarżeń o hipokryzję, związane z dziedziczeniem. Jeśli duchowny posiadał dzieci, to one przejmowały jego majątek, często pośród kłótni i swarów ${ }^{15}$.

W Afryce, choć rzadko, zdarzały się jeszcze przypadki, kiedy lud wybierał biskupa poprzez aklamację ${ }^{16}$. W ten sposób biskupem Hippony został

des Augustinus (354-430). Bezeugt in seinen Confessiones und abgebildet im Freskenzyklus des Benozzo Gozzoli, Books on Demand, Norderstedt 2014; K. Rosen, Augustinus. Genie und Heiliger, wbg Philipp von Zabern in Wissenschaftliche Buchgesellschaft, Wiesbaden 2015; R.L. Fox, Augustinus. Bekenntnisse und Bekehrungen im Leben eines antiken Menschen, Klett-Cotta, Stuttgart 2017.

12 Por. B. Degórski, Kler afrykański w świetle synodów IV i V wieku, „Vox Patrum” 6 (1986), z. 10, s. 219-238; J. Śrutwa, Przygotowanie do kapłaństwa w Afryce rzymskiej na podstawie pism św. Augustyna, „Vox Patrum” 13-14 (1993-1995), z. 24-29, s. 267-273. Natomiast szerzej o chrześcijaństwie i jego strukturach w Afryce w interesującym nas okresie por. E. Isichei, A History of Christianity in Africa. From Antiquity to the Present, Grand Rapids, Lawrenceville 1995, s. 14-44; K. Hock, Das Christentum in Afrika und dem Nahen Osten, Evangelische Verlagsanstalt, Leipzig 2005; T. C. Oden, How Africa Shaped the Christian Mind: Rediscovering the African Seedbed of Western Christianity, IVP Academic, Downers Grove 2007, s. 9-100; F. Decret, Early Christianity in North Africa, Wipf \& Stock Publ., Eugene 2009. Zaś o chrześcijaństwie w Afryce bizantyjskiej i jego pozycji po arabskich podbojach por. C. J. Speel, The Disappearance of Christianity from North Africa in the Wake of the Rise of Islam, „Church History: Studies in Christianity and Culture" 29/4 (1960), s. 379-397.

13 J. Saint-Martin, Le travail des moines, Desclée de Brouwer, Paris 1949, s. 71.

14 Por. Augustinus, Sermo 356, 2-14, PL 38.

15 Tenże, Sermo 355, II, 3, PL 38.

16 Augustinus, En. in Ps. 36 (2), 20, PL 36. 
Augustyn ${ }^{17}$. Homilie w danym mieście wygłaszał biskup, co było zgodne $\mathrm{z}$ afrykańską tradycją, a nie prezbiter, jak miało to miejsce w Italii ${ }^{18}$. Augustyn zezwalał jednak w swoim biskupstwie na takie praktyki, szczególnie jeśli prezbiter był wykształcony i posiadał dar wymowy ${ }^{19}$.

Niewielki procent społeczeństwa afrykańskiego rezygnował z życia poprzez odejście „na pustynię”, gdzie oddawano się rozważaniom Pisma Świętego ${ }^{20}$. Niektórzy z mnichów zapuszczali długie włosy, by poprzez upodobnienie się do nazirejczyków otrzymywać większe datki na utrzymanie ${ }^{21}$. Inni rezygnowali z małżeństwa ${ }^{22}$. W Kartaginie przed rokiem 400/401 zaczęły powstawać zorganizowane klasztory, gdzie żyli mnisi utrzymujący się z własnej pracy ${ }^{23}$ na rzecz całej społeczności klasztornej ${ }^{24}$. Głównym zadaniem klasztorów w społeczeństwie afrykańskim, abstrahując od celów duchowo-religijnych, było rozdzielanie jedzenia potrzebującym ${ }^{25}$. Pewnym problemem byli leniwi zakonnicy, którzy poświęcali się tylko źle pojętej kontemplacji, pracę pozostawiając świeckim ${ }^{26}$. Niektórzy z mnichów upadali z różnych przyczyn i odchodzili z klasztorów, by wieść świeckie życie ${ }^{27}$ lub odchodzili z powodów ideologicznych ${ }^{28}$. Kwestia ta najczęściej nękała młodych zakonników i zakonnice ${ }^{29}$, z czego częściej z problemem tym

17 Tenże, Ep. 31, 4, CSEL 34/2. Nie było to aż tak wyjątkowe w ówczesnym czasie, ponieważ inny z wybitnych członków Kościoła, tym razem w Italii, św. Ambroży, również wybrany został biskupem przez aklamację ludzi zgromadzonych w mediolańskiej bazylice. Widzimy więc, że zwyczaj ten, pochodzący z pierwszych wieków chrześcijaństwa, w późnoantycznym Imperium Rzymskim nie zanikł. Por. Ambrosius, Ep. 82, 3-11, CSEL 82/3; F. D. Gilliard, Senatorial Bishops in the Fourth Century, „The Harvard Theological Review” 77/2 (1984), s. 167-168. Ostatnio problemem wyboru Ambrożego zajął się D. Spychała, który po przedstawieniu swojej argumentacji skłania się ku interwencji władz rzymskich, a nie boskich, jak chciał widzieć to Paulin z Mediolanu, biograf Ambrożego. Por. D. Spychała, Wybór Ambrożego Aureliusza na biskupa Mediolanu: cud czy celowe działanie Walentyniana I?, „Studia Europeae Gnesnensia” 9 (2014), s. 75-93.

18 Por. Possidius, Vita Augustini V, 4, PL 32. Na temat głoszenia homilii przez prezbiterów por. K. Panuś, Zarys historii kaznodziejstwa w Kościele Katolickim, z. 1, Kaznodziejstwo w Kościele Powszechnym, Wydawnictwo „M”, Kraków 1999, s. 54-55, 58-60.

19 Possidius, Vita Augustini V, 3, PL 32.

20 Augustinus, En. in Ps. 54, 9-10, PL 36.

21 Tenże, De op. mon. XXI, PL 40.

22 Tenże, En. in Ps. 127, 1, PL 37.

23 Por. tenże, Retract. II, 47 (21), 1, PL 32; tenże, En. in Ps. 103 (3), 6, PL 37.

24 Tenże, De op. mon. XXV, 32, PL 40.

25 Tenże, De mor. eccl. man. I, 67, PL 32.

26 Tenże, De op. mon. I, 1-2, PL 40.

27 Tenże, De correptione et gratia I, 1, PL 44.

28 Tenże, De dono pers. XV, 38, PL 45.

29 Tenże, Sermo 355, IV, 6, PL 38. 
borykały się właśnie kobiety ${ }^{30}$. Być może wyjaśnieniem jest to, że często wybierały klasztorne życie za namowami i pod presją swoich matek ${ }^{31}$. Często też stroje zakonnic nie były tak skromne, jak wymagały tego zasady, co również doprowadzało do różnego rodzaju zamierzonych (lub nie) nieporozumień $^{32}$. Głównym źródłem utrzymania klasztorów żeńskich w Afryce rzymskiej było tkactwo ${ }^{33}$.

Uważać też należało na oszustów i kuglarzy, którzy próbowali udawać mnichów oraz duchownych ${ }^{34}$. Jak wynika ze słów Augustyna, większość z fałszywych kapłanów powiązana była ze środowiskiem circumcelliones i donatystów ${ }^{35}$. Jeśli chcielibyśmy przyjąć taką hipotezę, musimy pamiętać o niechęci katolickiego Augustyna do schizmy donatystycznej. Utożsamianie fałszywych kapłanów z donatystami i powiązanymi z nimi circumcelliones mogło być elementem propagandy antydonatystycznej. Niemniej problem fałszywych kapłanów był dość poważny, zwodzili oni i oszukiwali ludzi ${ }^{36}$, którzy potem skarżyli się hierarchii kościelnej - skarg tych skądinąd było całkiem sporo $^{37}$. Sprzedawali relikwie (w większości podrabiane) ${ }^{38}$, na które w społeczeństwie afrykańskim był duży popyt. Ich działalność określano jako lucrosa egestas ${ }^{39}$.

Ponadto praktykowano posty ${ }^{40}$, ich intensywność i rodzaje zależały od decyzji biskupa danego miejsca ${ }^{41}$. W Afryce najczęściej dzień postny stanowiła sobota ${ }^{42}$. Znane były przypadki, gdy nazbyt gorliwie praktykujący posty umierali z głodu ${ }^{43}$.

Duchowni czasami podróżowali po prowincjach rzymskich za zgodą swoich biskupów. Augustyn wspomina o zakonniku-kapłanie Sewerze,

\footnotetext{
30 Tenże, En. in Ps. 75, 17.

31 Tenże, De bono vid. 8, 11, PL 40.

32 Tenże, De sancta virg. 34, PL 40. Na ten temat por. Ioannis Chrysostomus, De virginitate, PG 48, gdzie św. Jan Chryzostom krytykuje, dokładnie wyliczając, różne elementy ubioru zakonnic.

33 Augustinus, De mor. eccl. man. I, 68, PL 32.

34 Tenże, En. in Ps. 132, 4, PL 37.

35 Tamże 132, 6, PL 37.

36 Tamże 109, 11, PL 37.

37 Tenże, De op. mon. XXVIII, 36, PL 40.

38 Tamże.

39 Tamże.

40 Tenże, En. in Ps. 86, 9, PL 37.

41 Tenże, Ep. 36, XIV, 32, CSEL 34/2.

42 Tenże, Ep. 45, I, II, 2, CSEL 34/2.

43 Tenże, En. in Ps. 106, 6-7, PL 37.
} 
który odwiedzał Afrykę z cyklem kazań i był bardzo popularną postacią w świecie chrześcijańskim ${ }^{44}$.

W Kościele afrykańskim czasów św. Augustyna przestrzegano rozdziału na $\mathrm{płcie}^{45}$. W trakcie sprawowania liturgii i kazania stano ${ }^{46}$. Podczas nabożeństw wspólnie śpiewano i czyniono to chętnie ${ }^{47}$. Psalmy śpiewano przy dźwiękach harfy ${ }^{48}$, a głosem prowadzącym wiernych był najczęściej lektor ${ }^{49}$. Alleluja śpiewano tylko w uroczyste dni, takie jak niedziele i święta ${ }^{50}$ Modlitwy również odmawiano głośno ${ }^{51}$, w pozycji stojącej zwróconej ku wschodowi ${ }^{52}$. W trakcie odczytywania Ewangelii św. Jana (J 8, 48), przy słowach, które padają do Chrystusa - „diabła masz” - uderzano się w piersi ${ }^{53}$. Spożywanie Ciała i Krwi Chrystusa dokonywano pod koniec liturgii ${ }^{54}$. W Afryce duchowni spożywali codziennie chleb eucharystyczny ${ }^{55}$.

\section{LAIKAT W KOŚCIELE AFRYKAŃSKIM}

Katechumenów, co jest sprawą oczywistą w chrystianizującym się społeczeństwie rzymskim, było sporo ${ }^{56}$. Listy osób, które miały przyjąć chrzest, tworzono w określonym czasie, zależnym od danego kościoła ${ }^{57}$. Oczywiście odbywano też burzliwe dyskusje dotyczące przyjmowania osób do chrztu ${ }^{58}$. Dzieci chrzczono tylko w zagrożeniu życia (odprawiano egzorcyzmy i czy-

44 Tamże 95, 2, PL 37. Niestety w Kartaginie zaniemógł i nie był w stanie wygłosić zaplanowanego kazania, za co Augustyn przepraszał wiernych.

45 Tenże, De civ. Dei II, XXVIII, PL 41.

46 Tenże, De cat. rud. XIII, 19, PL 40. Augustyn przywołuje jednak przykłady kościołów zza morza, gdzie były specjalne ławki dla osób słabszych.

47 Tenże, En. in Ps. 32 (2), 4, PL 36.

48 Tamże 4, 1, PL 36.

49 Tamże 138, 1, PL 37.

50 Tamże 106, 1, PL 37.

51 Tamże 3, 4, PL 36.

52 Tenże, De sermo Dom. in monte 2, 5, 18, PL 34.

53 Tenże, En. in Ps. 48 (2), 4, PL 36.

54 Tenże, De Trinitate III, X, 21, PL 42.

55 Tenże, De sermo Dom. in monte 2, 7, 26, PL 34. Z kolei na Wschodzie tak nie czyniono, co Augustyn ganił w ostrych słowach. Jak widać, Kościół był wówczas kościołem żywym, gdzie w niektórych kwestiach wiary różne Kościoły miały różne tradycje. Na ten temat szczególnie por. tenże, Ep. 54, I, II, 2, CSEL 34/2.

56 Tenże, De nupt. et conc. I, 4,5-5,6, PL 44. Świadczy to również o postępach chrystianizacji $\mathrm{w}$ regionie.

57 Tenże, Conf. IX, 6, PL 32.

58 Tenże, De fide et op. I, 2, PL 40. 
niono „tchnienie” nad dziećmi ${ }^{59}$ ), natomiast zwyczajowo czekano na dojrzalszy wiek, żeby w pełni zrozumiana została idea chrztu ${ }^{60}$. Dużo osób przyjmowało też chrzest, kiedy nie dało się go już dłużej odwlekaćc1 - było to związane z powszechnie panującym przekonaniem, że lepiej stanąć przed Bogiem mając jak najmniej grzechów na sumieniu. Katechumeni uczęszczali na specjalne katechezy chrzcielne ${ }^{62}$. Chrzest katechumenów, którzy dopiero po nim mogli być wprowadzeni w Eucharystię ${ }^{63}$, rozpoczynał się od odprawienia egzorcyzmów, a następnie udzielano chrztu wody ${ }^{64}$. Dniem chrztu tradycyjnie była sobota ${ }^{65}$. Katechumen tydzień wcześniej egzaminowany był ze Składu Apostolskiego, a w dzień chrztu z Modlitwy Pańskiej $^{66}$. „Symbolum nemo scribit, ut legi possit” ${ }^{97}$. Chrztu mogli udzielić tylko ci, qui ordinatur, posiadający sakramenty święceń ${ }^{68}$, czyli możliwość tzw. nałożenia rąk ${ }^{69}$. Po chrzcie należało przez kilka dni powstrzymywać się od stosunków płciowych ${ }^{70}$. Problemem hierarchii w Afryce były również powtórne chrzty udzielane przez donatystów ${ }^{71}$.

Dla Kościoła osobną kategorię świeckich, którzy mogli i powinni angażować się w sprawy duchowne stanowiły wdowy, których było niemało - powinny one wytrwać w czystości, najlepiej poświęcając się kontemplacji, ale nie musiały, często powtórnie wychodziły za mąż $\dot{z}^{72}$.

Świeccy ponadto pełnili różne posługi w Kościele afrykańskim, poczynając od udzielania darowizn a kończąc na asyście liturgicznej ${ }^{73}$. Chlubili się też swoją wiarą, nosząc znak krzyża na widocznych miejscach, niektórzy nawet na czołach ${ }^{74}$.

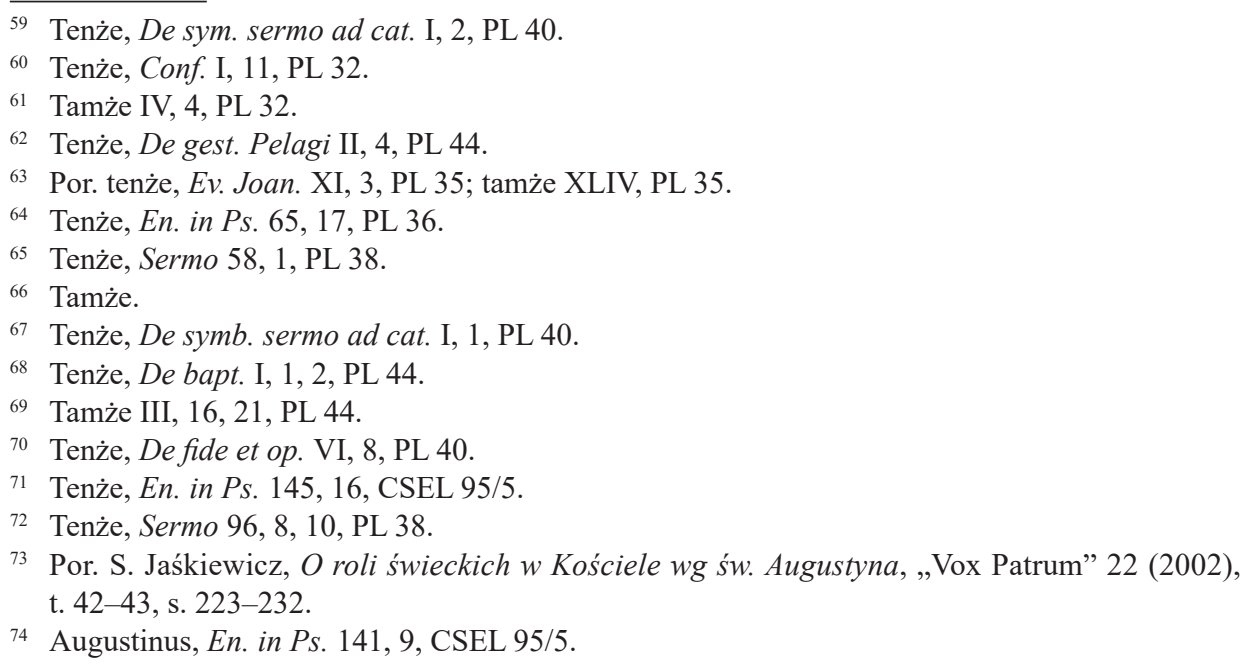


Ciężkimi grzechami były cudzołóstwo, morderstwo i świętokradztwo ${ }^{75}$. Często publicznie wyznawano grzechy w Kościele ${ }^{76}$. Należało wówczas obejść ołtarz, żeby dostąpić usprawiedliwienia i odpuszczenia win ${ }^{77}$, oczywiście tylko w przypadku, jeśli kapłan wcześniej wyraził na to zgodę.

Byli też i tacy, którzy wykorzystywali fakt bycia chrześcijaninem do zdobycia doczesnych korzyści ${ }^{78}$. Nawracały się wszystkie warstwy społeczne, niezależnie od majątku, jednak powody nawróceń mogły być różne ${ }^{79}$. Połowiczne nawrócenia były dość dużym problemem ${ }^{80}$, niektórzy nawet przed chrztem otwarcie przyznawali, że dalej będą czcić dawnych bogów ${ }^{81}$. Zmiany w świadomości ludzi nie dokonywały się tak szybko, jak postępy (czasami pozorne) chrystianizacji w Imperium Romanum. Ponadto wielu ludzi zauważyło nowe tendencje i koniunktury, toteż nawracali się tylko i wyłącznie powodowani oczekiwaniami materialnych korzyści bądź urzędniczego awansu.

Do wygłaszania homilii i kazań należało posiadać duży talent. Wiemy, że kazania Augustyna cieszyły się wśród ludzi dużą popularnością ${ }^{82}$, o czym świadczyć mogą chociażby prośby o powtórzenie treści jego wypowiedzi z dni wcześniejszych ${ }^{83}$. Przychodzili na nie zarówno ludzie wykształceni jak i prości robotnicy i niewolnicy ${ }^{84}$. W soboty wyjaśniał psalmy, co gromadziło dużo ludzi ${ }^{85}$, choć nie były to obowiązkowe nabożeństwa. Niektórzy z jego braci w wierze zapisywali słowa wygłaszane przez biskupa Hippony, żeby każdy mógł je później usłyszeć lub przeczytać ${ }^{86}$. Zdarzały

75 Tenże, De lib. arb. I, III-6, PL 32.

76 Tenże, En. in Ps. 101 (2), 3, PL 37.

77 Tamże 25 (2), 10, PL 36.

78 Por. tamże 7, 9, PL 36; tamże 47, 8, PL 36. Świadczy to o powszechności koniunkturalnych nawróceń.

79 Tenże, De cat. rud. VIII, 12, PL 40.

80 Tenże, De cat. rud. XVII, 2-6, PL 40. Dotyczyło to także innych części Cesarstwa. Niech świadczy o tym chociażby Maksym z Turynu, który też grzmiał na swoich wiernych, że w domach wciąż czczą bożki pogańskie. Por. Maximus Taurinensis, Sermo 30, 1-2, CCSL 23; tenże, Sermo 107, 1-2, CCSL 23. Podobnie zauważał ten problem Leon Wielki, przy czym zwracał on uwagę, że często dochodzi do porwań przez pogan chrześcijańskich dzieci na terenach granicznych (zapewne chodziło o nieochrzczone plemiona barbarzyńskie). Por. Leo I Magnus, Ep. 167, 19, PL 54.

${ }^{81}$ Augustinus, De fide et op. XII, 18, PL 40.

82 Por. tenże, Ev. Joan. IV, 9; VII, 24; X; 4-9, PL 35. Ludzie przybywali gromadnie nawet pomimo niesprzyjających warunków pogodowych. Por. tamże VI, 1, PL 35.

83 Tenże, En. in Ps. 33 (2), 1, PL 36.

84 Tamże 38, 18, PL 36.

85 Tamże 33 (1), 11, PL 36.

86 Tamże 51, 1, PL 36. 
się jednak dni, kiedy frekwencja nie dopisywała, czy to z powodu pogody czy odbywających się w tym czasie igrzysk lub przedstawień teatralnych ${ }^{87}$. „Et si aliquando vos diutius tenuimos, consilii fuit ut importunae horae transirent: arbitramur jam illos peregisse vanitatem suam" $"$.

Ludzie podczas kazań Augustyna wytrzymywali dość długo ${ }^{89}$ (co jak na żywiołowe, namiętne i egzaltowane społeczeństwo afrykańskie ${ }^{90}$ było olbrzymim sukcesem) i słuchali najczęściej z uwagą i zaciekawieniem ${ }^{91}$, jednak nie zawsze było to możliwe ${ }^{92}$. Sama chociażby lektura Enarrationes in Psalmos pozwala zauważyć, że kazania Augustyna cieszyły się względnie dużą i stałą popularnością wśród ludzi. Sam biskup dbał o to, żeby jego wierni nie zmęczyli się i znudzili. Ze spisanych tekstów kazań wyłania się nam obraz społeczeństwa chrześcijańskiego chętnego słuchaniu biskupa erudyty, a co ciekawe, w większości publikę stanowili ludzie niewykształceni ${ }^{93}$. Do kościoła przyciągała ich w pewnym sensie nie tylko chęć poznania tajemnic Psalmów, ale też osoba charyzmatycznego kaznodziei, człowieka, który w młodości popełniał błędy i żył tak jak oni, nie wstydząc się o tym mówić. Mimo wszak różnic i sporów doktrynalnych w Kościele afrykańskim ${ }^{94}$, Augustyn nie ustrzegł się pewnej chełpliwości w jego opisie. Jak sam stwierdzał, „Africa sola bene olet, totus mundus putet”95.

Pod koniec IV wieku i na początku V na limesie i nawet poza nim próbowano nawracać pogan, ale pomimo zachwytów Augustyna i głoszenia przezeń sukcesów ${ }^{96}$, musimy być ostrożni w ocenie oraz pamiętać o nawróceniach

87 Miało to miejsce chociażby w św. Wawrzyńca. Por. tenże, Sermo 303, 1, PL 38. Częstym powodem słabej frekwencji były właśnie także igrzyska czy przedstawienia organizowane „przypadkowo” przez pogan w dni święte dla chrześcijan. Por tenże, Sermo 311, 5, PL 38

88 Tenże, Ev. Joan. VII, 24, PL 35.

89 Oczywistym jest, że Augustyn jako znany i lubiany biskup miał dobrą frekwencję. Z lektury jego słów możemy domniemywać, że nie wszyscy kaznodzieje cieszyli się taką popularnością.

90 A. G. Hamman, Życie codzienne pierwszych chrześcijan, dz. cyt., s. 24.

91 Augustinus, En. in Ps. 53, 10, PL 36.

92 Por. tamże 34 (1), 15, PL 36; tamże 35, 19, PL 36; tamże 38, 23, PL 36; tamże 42, 1, PL 36; tamże 48 (1), 2, 17, PL 36; tamże 58 (1), 22, PL 36; tamże 58 (2), 1, PL 36; tamże 68 (2), 12, PL 36.

93 Tamże 32 (2), 5, PL 36.

94 Ogólnie o herezjach, sporach i kontrowersjach w Kościele w interesującym nas okresie por. R. Kosiński, Religie Cesarstwa Rzymskiego w V stuleciu, w: Świat rzymski w V wieku, red. R. Kosiński, K. Twardowska, Historia Iagellonica, Kraków 2010, s. 365-396.

95 Augustinus, En. in Ps. 21 (2), 2, PL 36. Niewątpliwie mamy tu do czynienia ze swoistym lokalnym patriotyzmem biskupa Hippony.

96 Tenże, Ep. 199, 12, CSEL 34/2. O działalności misyjnej katolików w Afryce por. T. Kotula, Św. Augustyn a barbarzyńcy afrykańscy, w: Grecy, Rzymianie i ich sasiedzi, pod red. K. Nawotki i M. Pawlak, „Antiquitas” XXIX (2007), s. 609-614. 
koniunkturalnych ${ }^{97}$. Nawet w prowincji prokonsularnej bowiem zdarzały się posiadłości i miejscowości, gdzie w ogóle nie było chrześcijan ${ }^{98}$. Sam Augustyn nie krył swoich pogańskich korzeni. Wszyscy w Kartaginie i okolicy znali przeszłość biskupa Hippony ${ }^{99}$, chociaż jego Confessiones miały przede wszystkim charakter dydaktyczny i zachęcający do przyjmowania chrześcijaństwa ${ }^{100}$.

\section{ZAGROŻENIA DLA KOŚCIOEA AFRYKAŃSKIEGO}

Wraz z postępującą chrystianizacją regionu afrykańskiego pojawiały się, rzecz jasna, herezje, takie jak apolinaryzm ${ }^{101}$, arianizm ${ }^{102}$, manicheizm ${ }^{103}$, pelagianizm ${ }^{104}$

97 O nawróceniach koniunkturalnych w Cesarstwie Rzymskim por. R. MacMullen, Christianizing the Roman Empire (A.D. 100-400), Yale University Press New Haven-London 1984, s. 83-85; J. Pałucki, Nawrócenia w IV wieku. Motywy oraz reperkusje społeczne, „Vox Patrum” 17 (1997), z. 32-33, s. 187-197; D. Kasprzak, Duszpasterze V wieku. Studium porównawcze myśli pasterskiej św. Piotra Chryzologa i Salwiana z Marsylii, Wydawnictwo UNUM, Kraków 2008, s. 13; tenże, Kościót IV i V wieku a połowiczne nawrócenia na chrześcijaństwo, w: Problemy duszpasterskie starożytnego Kościoła, red. J. Pałucki, Wydawnictwo KUL, Lublin 2009, s. 161-183; M. Wojcieszak, Obraz społeczeństwa Italii w listach Ambrożego z Mediolanu, „Christianitas Antiqua" VI (2014), s. 177-180.

98 Augustinus, En. in Ps. 68 (1), 16, PL 36.

99 Tamże 36 (3), 19, PL 36.

${ }^{100} \mathrm{Na}$ temat nawrócenia Augustyna por. W. Eborowicz, Proces nawrócenia św. Augustyna, „Vox Patrum" 14 (1988), s. 67-81; J. Scott, From Literal Self-Sacrifice to Literary Self-Sacrifice: Augustine's Confessions and the Rhetoric of Testimony, w: Augustine. From Rhetor to Theologian, s. 31-50; P. Paciorek, Świętego Augustyna Confessiones: dialog i świadectwo, „Vox Patrum” 17 (1997), z. 32-33, s. 215-221.

${ }_{101}$ Augustinus, En. in Ps. 29 (2), 2, PL 36.

102 Por. tenże, De Trinitate V, VI, 7, PL 42. O arianizmie i stosunku do niego panujących rzymskich władców por. D. Spychała, Cesarze rzymscy a arianizm. Od Konstantyna Wielkiego do Teodozjusza Wielkiego (312-395), Wydawnictwo Contact, Bydgoszcz 2007.

${ }^{103}$ Por. Augustinus, De mor. Eccl. et man., PL 32; tenże, En. in Ps. 9, 31, PL 36; tenże, De agone chr. IV, 4, PL 40; tenże, De bono con. 25, 33, PL 40; tenże, De continentia 9, 22; 10, 24, PL 40.

${ }^{104}$ Por. tenże, De natura boni $12 \mathrm{nn}$, CSEL 25; tenże, Ep. 157, 4, 23, CSEL 44; tenże, Ep. 186, 32-33, CSEL 57; tenże, Ep. 217, CSEL 57; tenże, Retract. I, 8, 3, PL 32; tamże II, 73 (47), 1, PL 32; tamże II, 76 (50), 1, PL 32; tamże II, 87 (61), 1, PL 32; tenże, Sermo 348a, PL 39; tenże, De bono vid. 19, 22, PL 40; tenże, De gratia et lib. arb. XIV, 30, PL 44; tamże XIX, 40, PL 44; tenże, De nuptiis et conc. I, 1, 1; I, 35, 40, PL 44; tenże, De praedest. sanct. I, 2, PL 44; tamże II, 3, PL 44; tenże, Contra Iulianos, PL 44 (całe dzieło jest antypelagiańskie); tenże, De dono pers. IX, 29, PL 45; tamże XII, 31, PL 45. O pelagianizmie por. R. Toczko, Pelagiusz widziany oczami św. Augustyna, św. Hieronima, Pawła Orozjusza i Mariusza Mercatora, „Vox Patrum” 31 (2011), t. 56 , s. $699-712$. 
czy sabelianizm (patrypasjanizm) ${ }^{105}$ oraz schizmy ${ }^{106}$, spośród których najbardziej znaną był donatyzm ${ }^{107}$, stanowiące spory problem w rzymskiej Afryce w IV i V wieku ${ }^{108}$, a jednocześnie biskupów martwiła ich rosnąca popularność w społeczeństwie ${ }^{109}$. Było również wiele innych, pomniejszych ruchów heretyckich, a głosiciele fałszywych nauk zawsze mogli liczyć na naiwność ludzi ${ }^{110}$. Jedną z ciekawszych takich niewielkich grup byli ludzie, którzy na podstawie własnego rozumienia słów Starego Testamentu, wyliczali że Paruzja nadejdzie za siedem tysięcy lat ${ }^{111}$. Niewykluczone, że na takich lub podobnych wyliczeniach, niektórzy bardziej bystrzy Afrykańczycy, zarabiali pieniądze, dlatego być może ten temat poruszył akurat w swoim kazaniu Augustyn. Często też obecność heretyków wywoływała rozruchy w miastach i na wsiach ${ }^{112}$. Kościół prowadził także z ruchami heretyckimi aktywną walką intelektualną - organizowano dysputy oraz wydawano dzieła ortodoksyjnych pisarzy przeciw herezjarchom $\mathrm{i}$ ich ideom ${ }^{113}$.

Dość sporą grupę zwolenników manicheizmu można było znaleźć zwłaszcza w Kartaginie w II poł. IV wieku, gdzie swoją działalność prowadził heretycki

${ }^{105}$ Augustinus, Ev. Joan. XXXVI, 8-9, PL 35.

106 Tenże, En. in Ps. 101 (2), 8-9, PL 37.

107 Por. tenże, Ep. 33, CSEL 34/2; tenże, Ep. 34, 2, CSEL 34/2; tenże, Ep. 43, CSEL 34/2; tenże, Ep. 49, CSEL 34/2; tenże, Ep. 51, CSEL 34/2, tenże, Ep. 52, CSEL 34/2; tenże, Ep. 52, 2-4, CSEL 34/2; tenże, Ep. 70, CSEL 34/2; tenże, Retract. II, 31 (5), 1-2, PL 32; tamże II, 43 (17), 1-3, PL 32; tamże 44 (18), 1, PL 32; tamże 45 (1), PL 32; tamże 52 (26), 1, PL 32; tamże 53 (27), 1-2, PL 32; tamże 54 (28), 1, PL 32; tamże 65 (39), 1, PL 32; tamże 66 (40), 1, PL 32; tamże 72 (46), PL 32, tamże 74 (48), PL 32; tamże 85 (59), 1, PL 32; tenże, Ev. Joan. IV, 16, PL 35; tamże V, 13, PL 35; tamże VI, 11-12, 20, PL 35; tamże XIII, 14, PL 35; tenże, In ep. Joan. ad Parth. I, 2, PL 35; tamże III, 7, PL 35; tenże, En. in Ps. 33 (2), 7, PL 36; tamże 36 (2), 19, PL 36; tamże 36 (3), 19-20, PL 36; tamże 49, 3-9, PL 36; tamże 54, 16, PL 36; tamże 145, 16, CSEL 95/5; tenże, De doctr. Chr. III, XXX, 42, PL 34; tenże, De gestis Pelagi XII, 27, PL 44, tenże, Enchiridion XVII, PL 40; tenże, De bapt. II, 11, 16, PL 44.

108 Por. Augustinus, Conf. XII, 16-17, 21, PL 32; tenże, De vera rel. V, 8-9, PL 34; tenże, En. in Ps. 18 (2), 5-6, 11-12, PL 36; tamże 21 (2), 1, PL 36; tamże 64, 7, 10, PL 36; tamże 75, 7-8, PL 36; tamże 80, 14, PL 37; tamże 85, 19, PL 37; tamże 106, 14, PL 37; tamże 109, 11, PL 37; tamże 118 (26), 4, PL 37; tamże 138, 26, PL 37; tenże, Sermo 3, PL 38; tenże, Sermo 71, 19, 32, PL 38; tenże, Sermo 92, 2, PL 38; tenże, De div. quaest. ad Simpl. II, 1, 10, PL 40; tenże, De fide et op. IV, 6, PL 40; tenże, De cat. rud. XXV, 48, PL 40; tenże, De continentia 4, 11, PL 40, tenże, De civ. Dei XXI, 25, 1-4, PL 41.

109 Por. tenże, Ev. Joan. XVIII, 4, PL 35; tenże, En. in Ps. 103 (3), 5, PL 37; tamże 119, 9, PL 37; tamże 120, 12, PL 37; tenże, De sermo Dom. in monte I, 5, 13; II, 9, 31; II, 24, 78-81, PL 34; tenże, Contra ep. Manichaei quam voc. fund., PL 42; tenże, De haeresibus, PL 42

${ }_{110}$ Por. tenże, Ev. Joan. XCVI, 5, PL 35; tenże, En. in Ps. 31 (2), 18, PL 36.

111 Tamże 6, 1, PL 36.

112 Tamże 45, 13, PL 36.

113 Tamże 118 (6), 4, PL 37. 
biskup Faustus ${ }^{114}$. Odznaczali się oni przesadnym wręcz szacunkiem do płodów ziemi - sam Augustyn przyznaje, że manichejczycy, do których dołączył, potrzebującej, głodnej osobie spoza swojego grona odmówiliby kromki chleba, ponieważ oznaczałoby to skazanie tego kawałka chleba na śmierć ${ }^{115}$. Sami zaś nie jedli mięsa i roślin, z identycznych powodów ${ }^{116}$. Ponadto w ostatnich dekadach IV wieku manichejczycy zyskiwali ogólnie dość dużą popularność w miastach ${ }^{117}$.

Donatyzm był zdecydowanie jedną z największych schizm starożytnego Kościoła, która dotknęła wyłącznie tereny Afryki ${ }^{118}$. Walkę z nim utrudniała jego popularność i względna powszechność oraz współpraca donatystów z bandami circumcelliones ${ }^{119}$. W każdej warstwie społecznej można było odnaleźć donatystów, także wśród urzędników państwowych ${ }^{120}$. Czasami, żeby przejść ze strony katolickiej do donatystycznej, wystarczał konflikt interesów. Tak było w przypadku kapłana Prymusa, który skarcony za niewłaściwe zachowanie, obraził się i przyjął powtórny chrzest ${ }^{121}$, dołączając do schizmy ${ }^{122}$. W drugą stronę również zdarzały się transfery i były one częste ${ }^{123}$, co dowodzi tego, że wśród chrześcijan Afryki rzymskiej w czasach św. Augustyna żyło wciąż wielu donatystów; co więcej zaś, w niektórych rejonach katolicy byli w znacznej mniejszości ${ }^{124}$, jak na przykład w Bagai

\footnotetext{
114 Tenże, Conf. V, 3-6, PL 32.

115 Tamże III, 6, PL 32.

116 Tenże, De civ. Dei I, XX, PL 41.

117 Tenże, En. in PS. 10, 3, PL 36.

118 Na temat donatyzmu i walki z nim por. hasło donatismus w: RPTK XI, Leipzig 1898, s. 788-798; P. Gruszka, Autorytet Pisma Świętego w polemikach religijnych katolików z donatystami, „Antiquitas” XV (1989), s. 45-60; T. Kołosowski, Od wolności wyboru wyznania do przymusu religijnego. Ewolucja poglądów biskupa z Hippony podczas schizmy donatystycznej w Afryce rzymskiej, Offset Piła, Piła 2000, rozdz. I (dot. kontekstu historycznego); J. Ratzinger, Opera omnia, Lud i Dom Boży w nauce św. Augustyna o Kościele, dz. cyt., s. 188-249.

119 Augustinus, En. in Ps. 57, 19, PL 36.

${ }^{120}$ Por. tenże, Ep. 56, CSEL 34/2; tenże, Ep. 57, CSEL 34/2; tenże, Ep. 58, CSEL 34/2.

${ }^{121}$ Powtórzenie chrztu przez właściwego biskupa donatystycznego było warunkiem koniecznym dołączenia do tej schizmy. Por. Augustinus, En. in Ps. 32 (3), 29, PL 36.

122 Tenże, Ep. 35, 2, CSEL 34/2.

${ }^{123}$ Tenże, Ep. 20*, 3, Coll. Divjak. Quoniam non solum in civitatem multi homines, verum etiam in agris multae plebes accesserat ex parte Donati. Augustyn opisuje również przypadek jednego donatysty, który został w Kartaginie przyjęty na łono katolików, jednak nie otrzymawszy pożądanego stanowiska, wyrażał głośno swe niezadowolenie. Por. Augustinus, En. in Ps. 36 (2), 11, PL 36. Możemy zauważyć na tym przykładzie, że czasami transfery pomiędzy donatyzmem a katolicyzmem nie miały nic wspólnego z poglądami, tylko z czysto ludzkim pragnieniem chwały i sławy.

${ }^{124}$ Augustinus, En. in Ps. 30 (4), 7, PL 36.
} 
w Numidii, w Thamugade ${ }^{125}$ czy w części Libii - Getulii ${ }^{126}$. Obie strony prowokowały się nawzajem i nie szczędziły sobie wyzwisk, gdy mijali się na ulicy ${ }^{127}$. Cesarze popierali stronę katolicką w tym sporze ${ }^{128}$, dlatego też nie mogą dziwić rozkazy wysłane Makariuszowi, który miał na przełomie IV i V wieku zacząć wyciszać donatystów ${ }^{129}$ Jeśli chodzi o kwestie doktrynalne, to donatyzm nie różnił się niczym od katolicyzmu. Kością niezgody było na początku IV wieku traktowanie lapsi, czyli upadłych w czasie prześladowań chrześcijan. Donatyści organizowali swoje własne synody ${ }^{130}$. Zachęcali także ludzi, korzystając z ich niewiedzy, do wstąpienia w swoje szeregi ${ }^{131}$. W czasie rozmów wyjawiali tylko, że w Kościele jest wielu grzeszników, a oni są ze stronnictwa biskupa Donata, którzy pragną zbawienia, nie podając żadnych innych konkretnych informacji ${ }^{132}$. Zazwyczaj udawali też katolików ${ }^{133}$. Wykorzystywano również zależności, jakimi charakteryzowało się społeczeństwo afrykańskie. Biskup donatystyczny Kryspin, poprzez działania prawne związane z wykupem ziemi, przechrzcił osiemdziesięciu kolonów, którzy byli katolikami ${ }^{134}$. Było to wbrew ich woli, ale pamiętając o glebae adscripti, to biskup Kryspin w świetle obowiązującego prawa, nie zrobił niczego złego. Ponadto możemy domniemywać, że przy niekorzystnej sytuacji kolonów, nie opłacało im się stawiać oporu biskupowi, ponieważ mogło to tylko pogorszyć ich los.

Częste wspominanie donatystów w kazaniach Augustyna świadczy nie tylko o tym, że byli oni znaczącym problemem dla katolików, ale również o tym, że tracono na ich rzecz wiernych ${ }^{135}$. Również i przed Augustynem, św. Ambroży z Mediolanu zauważał, że dużym problemem dla jedności

\footnotetext{
125 Tamże 21 (2), 24, PL 36.

126 Tamże 148, 10, CSEL 95/5.

127 Tenże, Ep. 35, 4, CSEL 34/2.

128 Por. tenże, Ev. Joan. XI, 14, PL 35; tenże, In ep. Joan. ad Parth. X, 10, PL 35; tenże, De bapt. II, 10, 15, PL 44. Na podstawie tych fragmentów możemy zauważyć, że zaangażowanie w walkę z donatyzmem ze strony państwowej było dość spore. Ważną też jest konstytucja cesarska z 15 stycznia 409 r., która nakazuje ukaranie wszystkich donatystów. Dzięki niej mamy potwierdzenie także przejawów agresywnego zachowania donatystów względem katolików dochodziło do wyszydzania, pobić, a nawet tortur. Por. Cod. Th. XVI, 5, 46.

129 Augustinus, En. in PS. 10, 5, PL 36.

130 Tamże 21 (2), 31, PL 36.

131 Tamże 10, 1, PL 36.

132 Tamże 10, 4, PL 36.

133 Tamże 57, 19, PL 36.

134 Tenże, Ep. 105, 2, 4, CSEL 34/2.

135 Tenże, En. in PS. 39, 1, PL 36.
} 
Kościoła jest specyficzna tylko dla terenów Afryki rzymskiej schizma donatystyczna, której członkowie udzielają powtórnych chrztów (o czym była już mowa), a także wyświęcają własnych biskupów, co było całkowicie wbrew obowiązującym zasadom ${ }^{136}$.

\section{PODSUMOWANIE}

W taki właśnie sposób prezentowała się mozaika społeczności chrześcijan Afryki rzymskiej czasów św. Augustyna - jako miejsce bogate, ale pełne sprzeczności, nierówności między bogatymi a biednymi oraz konfliktów nie tylko społecznych, ale i religijnych. Afrykańczycy żywiołowo reagowali na różne wydarzenia czy zmiany w swoim życiu. Niepowodzenia chrześcijanie thumaczyli działaniem szatana, fatum lub złego losu, rzadko kiedy winę widząc w sobie ${ }^{137}$. Ludzie za porażki obwiniali wszystko i wszystkich ${ }^{138}$. Jeżeli ktoś nie wierzył drugiemu, zbywał go, mówiąc, że to babskie gadanie ${ }^{139}$, przy okazji wyrażając dezaprobatę poprzez popukanie się w czoło ${ }^{140}$. Oczywiście wszystko to działo się przy bardzo bogatej gestykulacji. Ludzie często też spluwali idąc ulicami ${ }^{141}$. Przytoczony tutaj tylko niewielki fragment opisu zachowania społeczeństwa afrykańskiego może nas już nakierować na trudności i problemy, jakie mogło ono sprawiać nie tylko urzędnikom cesarskim, ale i od IV wieku hierarchii kościelnej.

Wydarzenia polityczne również nie oszczędzały prowincji afrykańskich, które mimo niesprzyjających od III wieku okoliczności wciąż dobrze prosperowały. Narażona na ataki plemion z południa, uzurpacje czy krwawe w przebiegu konflikty religijne w późnym antyku, rzymska Afryka, której największy rozwój przypadł na II wiek po Chr. i tak pozostawała jednym z najwspanialszych obszarów Cesarstwa Rzymskiego nawet w momencie, gdy panowali nad nią Wandalowie (z krótką przerwą w latach 435-439 wymuszoną przez traktat pokojowy zawarty przez wysłanego do Afryki Aspara $^{142}$ ) i gdy w roku 530, dzięki wizji Justyniana oraz umiejętnościom

\footnotetext{
136 Por. Ambrosius, Ep. 7*, 6-7, CSEL 82/3.

${ }^{137}$ Augustinus, En. in Ps. 91, 3, PL 37.

138 Tamże.

139 Tamże 134, 20, PL 37.

140 Tenże, De bapt. V, 5-6, PL 40.

${ }^{141}$ Tenże, En. in Ps. 125, 7, PL 37.

${ }^{142}$ Aecjusz, praktycznie panujący nad zachodnią częścią Cesarstwa, poprosił o pomoc cesarza wschodniej części Imperium w rozwiązaniu problemu wandalskiego (sam musiał uporać się
} 
Belizariusza $^{143}$, na ponad półtora stulecia powróciła do Cesarstwa Bizantyjskiego ${ }^{144}$.

Kościół afrykański, co oczywiste, miał również swoje poważne problemy, przede wszystkim związane z koniunkturalnymi nawróceniami (które stanowiły wyzwanie w całym Imperium Rzymskim) oraz z rozwojem różnego rodzaju herezji i schizm, dążących do naruszenia jedności kościelnej. Zdecydowanie najpoważniejszą schizmą był powstały w pierwszych latach IV wieku donatyzm, którego zwolennicy w czasach św. Augustyna wciąż stanowili pewien procent wśród wyznawców Chrystusa. W kwestii licznych herezji biskup Hippony także nie pozostawał obojętny. Zwalczał apolinaryzm, arianizm, manicheizm, pelagianizm oraz sabelianizm.

W powyższych uwagach dotyczących chrześcijańskiego społeczeństwa Afryki rzymskiej, zawartych w pismach św. Augustyna, mogliśmy zaobserwować również kilka interesujących zjawisk oraz tradycji dotyczących życia codziennego świeckich, kleru oraz kształtowania się liturgii.

Kościół w Afryce rzymskiej epoki późnego antyku, mimo wszelkich przeszkód, rozwijał się prężnie, a związek miało to niewątpliwie z charyzmą i przykładem życia biskupa Hippony. Oczywiście w IV i V wieku wewnętrzną jednością Kościoła wstrząsały liczne herezje i schizmy, które wpływały na niepokój w społeczeństwie, jednak dzięki działalności katolickich biskupów i cesarzy, a także wsparciu Ducha Świętego, nie naruszały one w poważnym stopniu struktur kościelnych oraz pozwalały zachować tak potrzebną katolicką jedność w chrystianizującym się społeczeństwie Cesarstwa Rzymskiego.

jeszcze z poważnymi problemami w Galii. Walentynian III wysłał na pomoc Aspara, który zmusił Gejzeryka do zawarcia układu pokojowego w 435 roku, który jednak w 439 ten zerwał, korzystając z kolejnych słabości armii rzymskiej i niemożności utrzymania w wielu miejscach silnych oddziałów wojskowych. Na początku lat 40 . V wieku planowano wyprawy przeciwko Wandalom, jednak nic z tego nie wyszło. Por. P. Heather, Upadek Cesarstwa Rzymskiego, s. 335, 338-340. $\mathrm{Na}$ temat samego Aecjusza klasyczne studium napisał T. Mommsen. Por. T. Mommsen, Aetius, „Hermes” LXXVI (1901), s. 516-547.

${ }^{143}$ Por. L. Casson, Belisarius' Expedition Against Carthage, w: Carthage VII: Excavations at Carthage 1978 Conducted by the University of Michigan, ed. J. H. Humphrey, Kelsey Museum, University of Michigan, Ann Arbor 1992, s. 23-28.

${ }^{144} \mathrm{Na}$ temat dziejów Afryki wandalskiej i bizantyjskiej por. Ch. Diehl, L'Afrique Byzantine. Histoire de la Domination Byzantine en Afrique (533-709), Ernest Leroux, Paris 1896; D. Roques, La Guerre contre les Vandales (Guerres de Justinien, livres 3-4), Belles Lettres, Paris 1990; G. Tate, Justinien. L'épopée de l'Empire d'Orient (527-565), Fayard, Paris 2004; I. Hughes, Belisarius: The Last Roman General, Pen and Sword Military, Yardley 2009; P. Maraval, Justinien. Le rêve d'un empire chrétien universel, Tallandier, Paris 2016. 


\section{Bibliografia}

Acts of the Christian Martyrs, Oxford University Press, Oxford 1972.

Afrika und Rom in der antike, hrsg von H. J. Diesner, H. Barth, H.D. Zimmermann, Verlag Halle Univ., Halle 1968.

Ambrosius, Epistulae, CSEL 82/1, 82/3, 82/3.

Augustinus, Epistulae, CSEL 34/1, 34/2, 44, 57.

Augustinus, Confessiones, PL 32.

Augustinus, De Moribus Ecclesiae Catholicae et de Moribus Manichaeorum, PL 32.

Augustinus, Retractationum libri duo, PL 32.

Augustinus, De Doctrina Christiana, PL 34.

Augustinus, De Sermo Domini in Monte, PL 34.

Augustinus, De Vera Religione, PL 34.

Augustinus, In Epistolam Joannis Ad Parthos Tractatus Decem, PL 35.

Augustinus, In Evangelium Joannis Tractatus CXXIV, PL 35.

Augustinus, Enarrationes in Psalmos, PL 36-37.

Augustinus, Sermones, PL 38-39.

Augustinus, De Bono Viduitatis, PL 40.

Augustinus, De Catechizandis Rudibus, PL 40.

Augustinus, De continentia, PL 40.

Augustinus, De Diversis Quaestionibus Ad Simplicianum, PL 40.

Augustinus, De Fide Et Operibus, PL 40.

Augustinus, De Opere Monachorum, PL 40.

Augustinus, De Sancta Virginitate, PL 40.

Augustinus, De Symbolo Ad Catechumenos, PL 40.

Augustinus, Enchiridion, PL 40.

Augustinus, De Civitate Dei, PL 41.

Augustinus, Contra Epistolam Manichaei, PL 42.

Augustinus, De Haeresibus, PL 42.

Augustinus, De Trinitate, PL 42.

Augustinus, De Correptione et Gratia, PL 44.

Augustinus, De Gestis Pelagi, PL 44.

Augustinus, De Gratia Et Libero Arbitrio Ad Valentinum, PL 44.

Augustinus, De Nuptiis Et Concupiscentia, PL 44.

Augustinus, De Peccatorum Meritis Et Remissione Et De Baptismo Parvulorum, PL 44.

Augustinus, De Dono Perseverantiae, PL 45.

Bellinger G.J., Die Lebensgeschichte des Augustinus (354-430). Bezeugt in seinen Confessiones und abgebildet im Freskenzyklus des Benozzo Gozzoli, Books on Demand, Norderstedt 2014. 
Bettetini M., Augustinus in Karthago: gleich einem Roman, w: Die Confessiones des Augustines von Hippo. Einführung und Interpretationem zu den dreizehn Büchen, hrsg von N. Fischer, C. Mayer, Herder Freiburg, Freiburg-Basel-Wien 2004, s. 133-164.

Bohec Y. Le, L'Afrique romaine. 146 avant J.-C-439 après J.-C., Picard, Paris 2005.

Cabouret B., Arnaud-Lindet M.P., L'Afrique romaine de 69 à 439, Editions du Temps, Nantes 2005.

Campenhausen H. von, Ojcowie Kościoła, Wydawnictwo Cyklady, Warszawa 1998.

Casson L., Belisarius' Expedition Against Carthage, w: Carthage VII: Excavations at Carthage 1978 Conducted by the University of Michigan, ed. J.H. Humphrey, Kelsey Museum, University of Michigan, Ann Arbor 1992, s. 63-79.

Chadwick H., Augustyn, Prószyński i S-ka, Warszawa 2000.

Conant J., Staying Roman. Conquest and Identity in Africa and the Mediterranean, Cambridge University Press, Cambridge 2012.

Corbier P., Griesheimer M., L'Afrique romaine: 146 av. J.-C.-439 ap. J.-C., Ellipses Marketing, Paris 2005.

Cremona C., Augustin d'Hippone, Éditions Pierre Téqui, Paris 1987.

Cyprianus, De Dominica Oratione, CCSL III A.

Decret F., Early Christianity in North Africa, Wipf \& Stock Publ., Eugene 2009.

Degórski B., Kler afrykański w świetle synodów IV i V wieku, ,Vox Patrum” 22 (2002), t. 42-43, s. 219-238.

Depositio martyrum, mense Martio, non. Martias Perpetuae et Felicitatis, Africae, MGH AA IX.

Diehl Ch., L'Afrique Byzantine. Histoire de la Domination Byzantine en Afrique (533-709), Ernest Leroux, Paris 1896.

Eborowicz W., Proces nawrócenia św. Augustyna, ,Vox Patrum” 14 (1988), s. $67-81$.

Eckmann, Św. Augustyn - duszpasterz, „Vox Patrum” 7 (1987), z. 12-13, s. $137-153$.

Eckmann A., Osobowość dobrego katachety w ujęciu św. Augustyna, ,Vox Patrum" 10 (1990), z. 18, s. 113-120.

Eckmann A., Św. Ambroży jako duchowy mistrz św. Augustyna, „Vox Patrum” 18 (1998), t. 34-35, s. 195-199.

Eslin J.C., Saint Augustin. L'homme occidental, Michalon, Paris 2002.

Euzennat M., Le limes de Tingitane, Editions du CNRS, Paris 1989.

Fox R.L., Augustinus. Bekenntnisse und Bekehrungen im Leben eines antiken Menschen, Klett-Cotta, Stuttgart 2017.

Geerlings W., Augustinus - Leben und Werk. Eine bibliographische Einführung, Verlag Ferdinand Schöningh, Paderborn 2002. 
Gilliard D., Senatorial Bishops in the Fourth Century, „The Harvard Theological Review" 77/2 (1984), s. 153-175.

Glay M. Le, Le paganisme en Numidie et dans les Maurétanies sous l'Empire romain: état des recherches entre 1954 et 1990, „Antiquités Africaines” 42 (2006), s. $57-86$.

Gołgowski T., Hippona dziś, „Vox Patrum” 8 (1988), t. 14, s. 415-421.

Gruszka P., Autorytet Pisma Świętego w polemikach religijnych katolików $z$ donatystami, „Antiquitas” XV (1989), s. 45-60.

Hamman A. G., Życie codzienne w Afryce Pólnocnej w czasach św. Augustyna, Instytut Wydawniczy PAX, Warszawa 1989.

Harmless W., Augustine in his own words, The Catholic University of America Press, Washington 2010.

Hughes I., Belisarius: The Last Roman General, Pen and Sword Military, Yardley 2009.

Hock K., Das Christentum in Afrika und dem Nahen Osten, Evangelische Verlagsanstalt, Leipzig 2005.

Hoffman-Salz J., Die wirtschaftlichen Auswirkungen der römischen Eroberung. Vergleichende Untersuchungen der Provinzen Hispania Tarraconensis, Africa Proconsularis und Syria, Franz Steiner Stuttgart, Mainz 2011.

Ibba A., Traina G., L'Afrique romaine: De l'Atlantique à la Tripolitaine (69-439 ap. J.-C.), Bréal, Paris 2006.

Ioannis Chrysostomus, De virginitate, PG 48.

Isichei E., A History of Christianity in Africa. From Antiquity to the Present, Grand Rapids, Lawrenceville 1995.

Jaśkiewicz S., O roli świeckich w Kościele wg św. Augustyna, „Vox Patrum” 22 (2002), t. 42-43, s. 223-232.

Kasprzak D., Duszpasterze V wieku. Studium porównawcze myśli pasterskiej św. Piotra Chryzologa i Salwiana z Marsylii, Wydawnictwo UNUM, Kraków 2008.

Kasprzak D., Kościót IV i V wieku a połowiczne nawrócenia na chrześcijaństwo, w: Problemy duszpasterskie starożytnego Kościoła, red. J. Pałucki, Wydawnictwo KUL, Lublin 2009, s. 161-183.

Kenrick P., Tripolitania, Silphium Press, London 2009.

Kołosowski T., Od wolności wyboru wyznania do przymusu religijnego. Ewolucja pogladów biskupa z Hippony podczas schizmy donatystycznej w Afryce rzymskiej, Offset Piła, Piła 2000.

Kotula T., Zgromadzenia prowincjonalne w rzymskiej Afryce w epoce późnego Cesarstwa, Zakład Narodowy im. Ossolińskich, Wrocław 1965.

Kotula T., Afryka Pótnocna w starożytności, Zakład Narodowy im. Ossolińskich, Wrocław 1972. 
Kotula T., Św. Augustyn a barbarzyńcy afrykańscy, w: Grecy, Rzymianie i ich sqqsiedzi, pod red. K. Nawotki i M. Pawlak, „Antiquitas” XXIX (2007), s. 609-614.

Kranz G., Augustinus. Sein Leben und Wirken, Matthias-Grünewald, Mainz 1994.

Lafond Y., Guiraud H., L'Afrique romaine: Ier siècle avant J.-C., début Ve siècle après J.-C., Presses Universitaires du Mirail, Toulouse 2005.

Lancel S., Saint Augustin, SCM Press, Paris 1995.

Leo I Magnus, Ep. 167, PL 54.

Mackensen M., Schneider G., Production centres of African Red Slip ware (2nd-3rd c.) in northern and central Tunisia: archeological provenance and reference groups based on chemical analysis, „Journal of Roman Archeology” 19 (2006), s. 163-190.

MacMullen R., Christianizing the Roman Empire (A.D. 100-400), Yale University Press New Haven-London 1984.

Manton L., Roman North Africa, Batsford Ltd., Batsford 1988.

Maraval P., Justinien. Le rêve d'un empire chrétien universel, Tallandier, Paris 2016.

Marec E., Monuments chrétiens d'Hippone ville Episcopale de Saint Augustin, Arts et Metiers Graphiques, Paris 1958.

Marrou H. I., Augustinus und das Ende der antiken Bildung, Verlag Ferdinand Schöningh, Paderborn-München-Wien-Zürich 1995.

Marrou H. I., Saint Augustin et l'augustinisme, Seuil, Paris 2003.

Maximus Taurinensis, Sermo 30, CCSL 23.

McLynn N. B., Ambrose of Milan: Church and Court in a Christian Capital, University of California Press, Oakland 1994.

Merrills A. H., Vandals, Romans and Berbers. New Perspectives on Late Antique North Africa, Routledge, Aldershot 2002.

Mommsen T., Aetius, „Hermes” LXXVI (1901), s. 516-547.

Moncaeaux P., Histoire littéraire de l'Afrique Chrétienne, vol. 1, Tertullien et les origines, Editions Ernest Leroux, Paris 1901.

O’Donnell J.J., Augustine. A New Biography, Harper Perennial, New York 2005.

Oden T.C., How Africa Shaped the Christian Mind: Rediscovering the African Seedbed of Western Christianity, IVP Academic, Downers Grove 2007.

Olszaniec Sz., Prefektura praetorio Italii, Illyrikum i Afryki (312-425 n. e.), Wydawnictwo Uniwersytetu Mikołaja Kopernika, Torun 2014.

Paciorek P., Świętego Augustyna Confessiones: dialog i świadectwo, „Vox Patrum" 17 (1997), z. 32-33, s. 215-221.

Pałucki J., Nawrócenia w IV wieku. Motywy oraz reperkusje społeczne, „Vox Patrum” 17 (1997), z. 32-33, s. 187-197. 
Panuś K., Zarys historii kaznodziejstwa w Kościele Katolickim, z. 1, Kaznodziejstwo w Kościele Powszechnym, Wydawnictwo „M”, Kraków 1999.

Perler O., L'Église principale et les autros sanctuaires chrétiens d'Hippone La Royale d'après les textes de saint Augustin, RÉAug 1 (1955), s. 299-343.

Pollman K., Saint Augustine the Algerian, Göttinger Forum für Altertumswissenschaft, Göttingen 2007.

Possidius, Vita Augustini, PL 32.

Przywara E., San Agustín. Perfil humano y religioso, Ediciones Cristiandad, Madrid 1984.

Ratzinger J. (Benedictus XVI), Ojcowie Kościoła. Od Klemensa Rzymskiego do Augustyna, Wydawnictwo Polskiej Prowincji Dominikanów „W drodze”, Poznań 2008.

Ratzinger J. (Benedictus XVI), Opera omnia. Lud i Dom Boży w nauce Augustyna o Kościele, Wydawnictwo KUL, Lublin 2014, t. 15.

Raven S., Rome in Africa, Routledge, London 1993.

Rosen K., Augustinus. Genie und Heiliger, wbg Philipp von Zabern in Wissenschaftliche Buchgesellschaft, Wiesbaden 2015.

Roques D., La Guerre contre les Vandales (Guerres de Justinien, livres 3-4), Belles Lettres, Paris 1990.

Rzymska Afryka Pótnocna. Scripta minora Tadeusza Kotuli, wybór i opracowanie M. Pawlak, K. Nawotka, A. Łoś, Historia Iagellonica, Kraków 2016.

Saint-Martin J., Le travail des moines, Desclée de Brouwer, Paris 1949.

Santi G., Agostino d'Ippona filosofo, Lateran University Press, Roma 2003.

Sarnowski T., Les représentations de villas sur les mosaïques africaines tardives, Zakład Narodowy im. Ossolińskich, Wrocław 1978.

Schilling O., Die Staats - und Soziallehre des hl. Augustinus, Herder, Freiburg im Breisigan 1910.

Seele P., Philosophie der Epochenschwelle. Augustin zwischen Antike und Mittelalter, De Gruyter, Berlin 2008.

Słomka J., Eklezjalno-teologiczne podstawy praktyki pokutnej wprowadzonej przez Cypriana w Kartaginie, „Śląskie Studia Historyczno-Teologiczne” 42/2 (2009), s. 24-37.

Speel C. J., The Disappearance of Christianity from North Africa in the Wake of the Rise of Islam, „Church History: Studies in Christianity and Culture” 29/4 (1960), s. 379-397.

Spychała D., Cesarze rzymscy a arianizm. Od Konstantyna Wielkiego do Teodozjusza Wielkiego (312-395), Wydawnictwo Contact, Bydgoszcz 2007.

Spychała D., Wybór Ambrożego Aureliusza na biskupa Mediolanu: cud czy celowe dziatanie Walentyniana I?, „Studia Europeae Gnesnensia” 9 (2014), s. 75-93. 
Spychała D., Przemiany religijne i kulturowe w zachodnich prowincjach Cesarstwa Rzymskiego od roku 306 do śmierci św. Augustyna, Wydawnictwo Uniwersytetu Kazimierza Wielkiego, Bydgoszcz 2016, tom 1.

Stewart J., African states and rulers, McFarland, Jefferson 2006.

Stranb J., Augustinus sorge um die regenaratio imperii. Das Imperium Romanum als civitas terrena, „Historisches Jahrbuch” 73 (1954), s. 36-60.

Strzelczyk J., Wandalowie i ich afrykańskie państwo, Państwowy Instytut Wydawniczy, Warszawa 1992.

Śrutwa J., Przygotowanie do kaplaństwa w Afryce rzymskiej na podstawie pism św. Augustyna, „Vox Patrum” 13-14 (1993-1995), z. 24-29, s. 267-273.

Świat rzymski w V wieku, red. R. Kosiński, K. Twardowska, Historia Iagellonica, Kraków 2010.

Tate G., Justinien. L'épopée de l'Empire d'Orient (527-565), Fayard, Paris 2004.

Terullianus, Ad martyras, CCSL I.

Tertullianus, De fuga in persecutione, CCSL II.

Tertullianus, De praescriptione, CPL 5.

Toczko R., Pelagiusz widziany oczami św. Augustyna, św. Hieronima, Pawła Orozjusza i Mariusza Mercatora, „Vox Patrum” 31 (2011), t. 56, s. 699-712.

Trapè A., Introduzione generale a sant 'Agostino, Citta Nuova Editrice, Roma 2006.

Vannier M. A., Saint Augustin, Entrelacs, Paris 2011.

Whittaker D., Ethnic discourses on the frontiers of Roman Africa, w: Ethnic Constructs in Antiquity. The Role of Power and Tradition, red. T. Derks, N. Roymans, Amsterdam University Press, Amsterdam 2009, s. 189-206.

Wilczyński M., Gejzeryk i ,czwarta wojna punicka”, Wydawnictwo Napoleon V, Oświęcim 2016.

Wilson A., Urban production in the Roman World: The View from North Africa, „Papers of the British School at Rome” 70 (2002), s. 231-273.

Wipszycka E., Kościół w świecie późnego antyku, Państwowy Instytut Wydawniczy, Warszawa 1994.

Wojcieszak M., Obraz spoleczeństwa Italii w listach Ambrożego z Mediolanu, „Christianitas Antiqua” VI (2014), s. 177-180.

Zagórski D., Commendavit nobis Dominus oves suas. Pasterska troska o wier$n y c h$ świetle Sermones św. Augustyna, Toruńskie Wydawnictwo Diecezjalne Wydawnictwo „Bernardinum”, Toruń - Pelplin 2013. 